\title{
FINANCIAL PERFORMANCE OF SHARIA BANKS BEFORE AND AFTER SPIN-OFF
}

\author{
Prima Naomi ${ }^{1}$
}

\author{
University of Paramadina, Jakarta, Indonesia ${ }^{1}$
}

\begin{abstract}
This research aimed at identifying whether Bank Umum Syariah (BUS), as the result of spin-off of Unit Usaha Syariah (UUS), has better performance compared to the period when they were still in the form of UUS. There are 4 out of 5 BUSes as a result of spin-off us as samples. The results indicate that: 1) the spin-off of UUS to become BUS has successfully increased the market share of each BUS; 2) there is no significant difference in the profitability before and after spin-off in most sample; 3) no significant difference related to the operational efficiency.
\end{abstract}

Keywords: Efficiency; Financial Performance; Sharia Bank; Spin-off; Profitability

\section{Introduction}

The law of the Republic of Indonesia No. 21 Year 2008 regarding Sharia Banking (2008) requires Bank Umum Konvensional (BUK) or Conventional Commercial Banks to spin-off their Sharia Business Units (UUS) no later than 2023. In this matter, the government would like to assert that the form of UUS in the banking industry is only temporary in nature. Fifteen years after 2008 or in 2023, there will be certainly no more UUS, but only in the form of full fledge bank namely Sharia Commercial Bank (BUS) and Sharia Rural Bank (BPRS). Seven years has passed since the issuance of the regulation on mandatory spin-off of Sharia Business Units (UUS). This means that there are still eight more years for Conventional Commercial Banks (BUK) that have UUS to spin off the UUS to become Sharia Conventional Bank (BUS), provided that the asset of the UUS has reached $50 \%$ of the value of its holding bank. Up to December 2015 we could see the movement of the total number of BUS and UUS since the issuance of regulation on mandatory UUS spin-off.

Table 1 shows that regardless of an increase in BUSs, there are still many sharia banks in the form of UUS. Another interesting fact is that there are several BUKs that choose the form of UUS as an entrance to the business of sharia banking. Whereas the Government has clearly stated that UUS is a temporary business form. The strongest reason for some BUKs to choose this form is the easy process for setting up a UUS both from the aspect of capital and time required.

Table 1. Total Sharia Banks from July 2008 - December 2015

\begin{tabular}{cccc}
\hline Type of Sharia Banks & July 31, 2008 & December 31, 2015 & Growth Rate \\
\hline Sharia Commercial Bank (BUS) & 3 & 12 & $300 \%$ \\
\hline Sharia Business Unit (UUS) & 28 & 22 & $-21 \%$ \\
\hline Total BUSs and UUSs & 31 & 34 & $10 \%$ \\
\hline
\end{tabular}

Setting up a UUS only requires permit from Bank Indonesia. As provided in Bank Indonesia Regulation (PBI) No. 11/3 /PBI/2009 regarding Sharia Commercial Bank (2009) as amended by PBI No. 15/13/PBI/2013 regarding Amendment to PBI No. 11/3/PBI/2009 regarding BUS (2013), the operational capital that needs to be set aside for setting up a UUS is minimum Rp100 billion.

\footnotetext{
${ }^{1}$ prima.naomi@paramadina.ac.id
} 
The capital requirement for setting up a BUS is provided for in article 5 of PBI No. 11/3/PBI/2009 regarding Sharia Commercial Bank (2009). Setting up of BUS intended here is not for the resolution or not related to the purpose of USS spin-off. The minimum paid up capital required is Rp 1 trillion. Meanwhile Bank Indonesia provides incentive for establishment of BUS for the purpose of UUS spin-off. The minimum mandatory paid up capital is stipulated lower specifically only Rp 500 billion, but this capital must be increased gradually to be at least Rp 1 trillion within ten years as from issuance of BUS business license (BI, PBI No. 11/10/PBI/2009 regarding Sharia Business Unit, 2009).

The capital requirements for setting up a BUS through conversion of BUK are different from the capital requirement for setting up a new BUS. PBI No. 11/ 15 /PBI/2009 concerning Change of Business Activities of Conventional Banks to become Sharia Banks (2009), only stipulates that the BUK to be converted must have Minimum Capital Provision Obligation (KPMM) ratio of minimum 8\% and has the core capital of minimum Rp100 billion.

Since the purpose of UUS spin-off expected by the government is to accelerate the growth of market share of sharia banks against national banks, and the purpose of spin-off in theory which is to maximize the company's performance, this research has the purpose to obtain empirical evidences in responding to the following questions: 1) Is the market share of BUSs as a result of spin-off against the national banks better compared to when they were still UUS?; 2) Is the profitability after becoming a BUS better compared to when they were still UUS?; 3) Does BUS as a result of spin-off operate more efficiently compared to the period when they were still UUS?

Ross, Westerfield, \& Jaffe (2010) stated that spin-off is a form of divestment, namely separation of a division from a holding company to become a new entity, in which the share of the entity as a result of this separation will be distributed to the shareholders of the holding company holding company. There are four reasons for the spin-off, according to Ross, Westerfield, \& Jaffe (2010). First, to sharpen the company's focused. Second, to facilitate investors in appraising the holding company and subsidiaries after the spin-off. Third, to ensure that additional incentive for the executives, usually in the form of shares, is directly linked to their performance. Fourth, the tax consequence of the spin-off process is better than in the company's sale process, because in the spin-off there is no cash flow to the holding company. Gaughan (2011) discussed spin-off in the context of company restructuring, in which spin-off is carried out because a division in the company has poor performance or no longer fit in the company's plan (refocusing strategy). With spin off, the holding company is expected to raise the value of shareholders. Brealey, Myers, \& Allen (2008) also disccus spin-off in the context of Corporate Restructuring specifically a new independent company formed from the result of separation of assets and operation of the holding company. The shares of the new company are distributed to the shareholders of the holding company.

\section{Literature Review}

Financial performance is the description of a company's financial condition in a certain period related to the aspect of fund raising or fund distribution, which is usually measured with the indicators of capital adequacy, liquidity, and profitability (Jumingan, 2011). One of the techniques to measure the financial performance of a company is using Financial Ratio. In this research, we use 3 categories of financial ratio to represent the company's financial performance. The first ratio is Market share Ratio, the second ratio is Profitability Ratio, and the third ratio is Efficiency Ratio. Market share is a part of actual sales (in term of total sales or in term of money value) of a product in a certain period of time and in a certain geographical area. Market in this situation is defined more as the sale performance of a type of product in the market, not a collection of buyers of a product (Nakanishi, Cooper, \& Masao, 2010). Market share is a percentage of a market measured in term of quantity or income (Farris, Bendle, Pfeiper, \& Reibstein, 2010). Profitability is the capacity of a company to generate profit in a certain period of time and at a certain level of sale, assets and share capital. Profitability is a part in the analysis of the company's financial ratio with the purpose of measuring the company's performance (Gibson, 2012). Cost to Income Ratio (CIR) is one of the main financial ratios which is important in appraising a bank. This ratio can depict the relation between the cost of the company and its income (Money Week, 2013). 


\section{Methodology}

The object in this research is BUS which formation become a legal entity of Conventional Bank and must be through the process of spin-off on the UUS owned by BUK. In this research, collection of samples is conducted through the approach of purposive sampling under the following criteria: a) BUS which is formed after issuance of Law No. 21 year 2008 regarding Sharia banking; b) information of BUS through the spin-off process on the UUS owned by BUK; c) The period of before and after UUS spin-off, each has lasted for minimum five years. The type of data used in this research is secondary data. Data in this research is obtained from the website of OtoritasJasaKeuangan (OJK) or Financial Service Authority, Website of Bank Indonesia (BI) and Website of BUS which is used as the research object. The data of research used is in the form of :1) Quarterly Publicized financial statements of BUS/UUS, 2) Statistical Report of Indonesian Banking. Variables in this research are several bank financial ratios that represent the performance of sharia bank, namely the ratio of market share, profitability ratio represented by 3 ratios namely ROA Ratio, Net Profit Margin (NPM) ratio, and ratio of Total Asset Turnover, as well as the efficiency ratio in carrying out business represented by Cost to Income Ratio (CIR).

Market share

The formula used to measure a bank's market share is:

\section{Remarks:}

$$
S i=\frac{T A i}{T A}(1)
$$

$\begin{array}{lll}\mathrm{Si} & = & \text { BUS/UUS market share } \mathrm{i} \\ \mathrm{TAi} & = & \text { Total BUS/UUS Asset } \mathrm{i} \\ \mathrm{TA} & = & \text { Total Assets of National Banks }\end{array}$

Profitability

There are three ratios that we use to measure profitability, i.e :

a. Return on Asset (ROA) Ratio

b. Net Profit Margin (NPM) Ratio

$$
\mathrm{ROA}=\frac{\text { Profit before Tax }}{\text { Total assets average }}
$$

c. Total Asset Turnover Ratio

$$
\text { NPM Ratio }=\frac{\text { Profit after Tax }}{\text { Operating Income }}
$$

$$
\text { Total Asset Turnover Ratio }=\frac{\text { Operating Income }}{\text { total assets Average }}
$$

Operational Efficiency

The Ratio of bank efficiency used in this research is Cost to Income Ratio (CIR).

$$
\mathrm{CIR}=\frac{\text { Operating Costs }}{\text { Operating Income }}
$$

This research will compare the financial performance before and after the spin-off of UUS each in the span of five years. As the publicized financial statements of UUS are only for quarterly period, and to enable comparison of data before and after the UUS spin-off, the balance sheet and profit and loss statement to be used to calculate the financial ratios are for quarterly period. Data analysis refers to the attachments OJK Circular Letter No. 18/SEOJK.03/2015 regarding Transparancy and Publication of Statements of Sharia Conventional Banks and Sharia Business Units, part II namely Guidelines on Preparation of Publicized Quarterly Report of Sharia Conventional Banks and part III namely Guidelines on Preparation of Publicized Quarterly Report of Sharia Business Units. Some adjustment is made in the data processing. As the data for this research uses quarterly financial statements, all data collected from Profit and Loss Statement such as operating income, funding cost, operating cost, PPAP cost, profit and loss after/before tax must first annualized.

The method to calculate annualized data is as follows; the data of a certain month is divided by 
the figure in the said month and then multiplied by 12 . For example, if we would like to calculate annualized operating income for September 2014, then the data of operating income from the Profit and Loss Statement for September 2014 divided by 9 then multiplied 12. In other words the formula of annualized data can be written as follows:

Data of month i $=$ (Data of month i) $/ \mathrm{i} \times 12$. Meanwhile, for the data of total assets taken from the Balance Sheet, the average value must be first calculated. The average total assets intended here are the average position of total assets in the beginning of year until the position of total assets in the reported month. For example, if we will calculate the average total assets in the position as quarter III 2014, then we calculate the average total assets from January 2014 to September 2014. Hence the formula to calculate the average total assets can be written as follows: Average TA month $\mathrm{i}=(\mathrm{TA} \mathrm{Jan}+\mathrm{TA} \mathrm{Feb}+\cdots+\mathrm{TA}$ month i) / i

\section{Hypothesis and Statistical Test}

For each research object, the hypothesis stipulated to be tested for all financial ratios to be examined is as follows:

Ho : No difference in ratio before and after spin-off

Ha : There is difference in ratio before and after spin-off

To test the above hypothesis, we use the testing steps as in figure 1

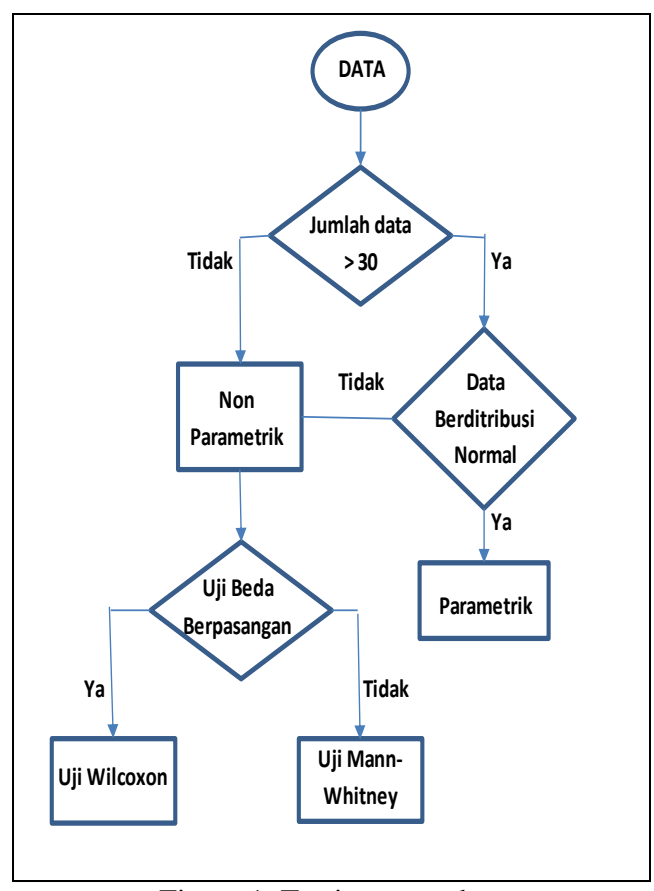

Figure 1. Testing procedure

The data in this research consists of two groups, namely the group of data before spin-off and the group of data after spin-off. As the total data from each group is less than 30, the statistical test used is usually non parametric test. However to ensure the above hypotheses, normality test is still administered using the Shapiro Wilk Test. If the result of normality test produces stipulation of type of ranon- tric test, then data would be proceed for paired data using Wilcoxon test. The reason for the use of paired data is beca parametric test used which is non-parametric, then the method to be applied is non-pameuse the data object is financial ratio deriving from the quarterly period and is influenced by the seasonal condition in each year. Preparation of paired data is carried out by pairing the data in the quarterly periods I, II, III, and IV in the first year before the spin-off paired with the quarterly periods I, II, III, and IV in the first year after the spin-off, and so forth. Statistical test and non-parametric Wilcoxon Test on the hypothesis in this 
research, is carried out using the SPSS Application version 23 instrument.

\section{Result and Discussion}

Based on the Statistics of Sharia banking issued by Bank Indonesia per December 2015, there are 5 UUSs that had been spun-off by their holding companies, from 28 UUSs that must be spun-off. The 5 UUSs that have undergone the process of spin-off to convert BUS are: 1) Bank Rakyat Indonesia Syariah (BRI Syariah); 2) Bank Negara Indonesia Syariah (BNI Syariah); 3) BPD Jawa Barat Banten Syariah (BJB Syariah); 4) Bank Syariah Bukopin; 5) Bank Tabungan PensiunanNasional Syariah (BTPN Syariah) The process which was taken by those five banks in implementing spin-off is divided into two, namely acquisition-conversion and pure spin-off. The grouping of spin-off process of UUS to become BUS can be viewed in table 2 .

Table 2. Spin-off Process of UUS to become BUS

\begin{tabular}{cc}
\hline Spin-off with Acquisition-Conversion & Pure Spin-off \\
\hline BRI Syariah & BNI Syariah \\
\hline Bank SyariaBukopin & BJB Syariah \\
\hline BTPB Syariah & \\
\hline
\end{tabular}

Source : (Annual report of BRI Syariah, 2010), (Annual report of BNI Syariah, 2010), (Annual report of BJB Syariah, 2010), (Annual report of Bank Syaria Bukopin, 2010)

Based on the criteria of samples research stipulated and the data of spin-off age as in table 3 , the research samples that can be used in this research are BRI Syariah, BNI Syariah, BJB Syariah, and Bank Syariah Bukopin.

Table 3. BUS Spin-off age of up to December 2015

\begin{tabular}{|c|c|c|c|}
\hline No. & BUS & UUS Spin-off & Spin-off Age per December 2015 \\
\hline 1 & BNI Syariah & Jun-10 & 6 years \\
\hline 2 & BRI Syariah & Jan-09 & 7 years \\
\hline 3 & BJB Syariah & May-10 & 6 years \\
\hline 4 & Syariah Bukopin & Jul-09 & 6 years \\
\hline 5 & BTPN Syariah & Jul-14 & 1 years \\
\hline
\end{tabular}

Source:(Annual report of BRI Syariah, 2010), (Annual report of BNI Syariah, 2010), (Annual report of BJB Syariah, 2010), (Annual report of Bank Syaria Bukopin, 2010)

The four BUSs of research objects mentioned above have respectively different time when they carried out UUS spin off. This will cause the time span of data examined for five years before and after spin-off for the four BUSs different depending upon the date of spin-off of each BUS.

Shapiro-Wilk Normality test is carried out to test the hypothesis of normality for each financial ratio per bank distinguished in the group of "before spin-off" and "after spin-off" with the significance value of 5\% or 0.05 . The result of Shapiro-Wilk normality test is obtained as in table 4 .

Based on the result of Significance value from Shapiro-Wilk test for each bank, per group data, and per financial ratio above, by using the Significance value of $5 \%$, we can conclude whether the data distributes normally or abnormally distributed. If the probability value $(p)$ is $>0.05$ it means that the data distributes normally. In table 4 , the data distributed normally is marked with *). There are 40 groups of data for 4 financial ratios from 4 sharia banks each of which is divided into group before spin-off and after spinoff. The result of Shapiro-Wilk test shows that 20 groups or $50 \%$ data pass normal distribution test. Meanwhile the remaining 20 groups of data do not pass the normal distribution test. Under this condition, the method of statistical test to be used is non-parametric. Subsequently, considering that the data of 
financial ratio for BUS in the quarterly period is influenced by the "seasonal" condition, the Wilcoxon test (paired data testing) is used to test the hypothesis whether there is a difference in the financial performance between the period before the spin-off and the period after the spin-off. The result of non-parametric Wilcoxon test is shown in table 5 .

Decision on the hypothesis test for the financial ratio of each bank is taken based on the value of $\alpha$ or significance value of 5\% (0.05) as well as the basic criteria for making decision on the statistical test as follows:

- $\quad$ If the value of Asymp. Sig. (2-tailed) is $>0.05$, Ho is not rejected

- If the value of Asymp. Sig. (2-tailed) is $<0.05$, Ho is rejected

The result of statistical test expected in this research on the 5 financial ratios is that the Ho is rejected, under the condition of mean rank positive for the ratios of market share, ROA, NPM, and Total Asset Turnover, whereas the mean rank negative for the CIR ratio. In table 5, each result of mean rank not corresponding to the expectations of the research (happenned the opposite ), is marked with italic letters.

Table 5 shows the market shares for the 4 Sharia banks, namely BRI Syariah, BNI Syariah, BJB Syariah and Bank Syariah Bukopin, all of which resulted in rejecting Ho. This means that after undergoing statistical test there are evidently difference in the market share ratio between the period before spin-off and the period of after spin-off, and produce the result of positive rank, which means that the market share ratio after the spin-off is greater than in the period before the spin-off.

For the same period used in this research, 5 years before and after the spin-off, the data of total national banking assets indicates a relatively stable growth. In the period of 5 years before the spin-off, the average growth rate of total national banking assets was $16 \%$. Whereas for the period of 5 years after the spin-off, the average growth rate of the total assets of national banks slightly decline to $14 \%$. Under the condition in which the total national banking assets is relatively stable, it can be concluded that the main cause of significant rise in the ratio of the BUS market share as a result of spin-off is indeed the spin-off process which cause significant increase of assets as a result of merger of BUK-conversion with UUS (spin-off acquisition- conversion), and injection of capital to BUS entities as a result of UUS spin-off (pure spin-off).

Table 4. Result of Shapiro-Wilk Tests of Normality

\begin{tabular}{|c|c|c|c|c|c|c|c|c|c|c|c|}
\hline $\begin{array}{l}\text { Bank } \\
\text { Name }\end{array}$ & Data Group & $\begin{array}{l}\text { Market } \\
\text { Share }\end{array}$ & & ROA Rat & & $\begin{array}{l}\text { NPM } \\
\text { Ratio }\end{array}$ & & $\begin{array}{l}\text { Total } \\
\text { Asset } \\
\text { Turnover } \\
\text { Ratio }\end{array}$ & & CIR & \\
\hline \multirow{2}{*}{$\begin{array}{l}\text { BRI } \\
\text { Syariah }\end{array}$} & Before Spin-off & 0.047 & & 0.033 & & 0.040 & & 0.572 & & 0.000 & \\
\hline & After Spin-off & 0.109 & $*$ & 0.028 & & 0.076 & $*$ & 0.027 & & 0.137 & $*$ \\
\hline \multirow{2}{*}{$\begin{array}{l}\text { BNI } \\
\text { Syariah }\end{array}$} & Before Spin-off & 0.009 & & 0.042 & & 0.105 & $*$ & 0.009 & & 0.000 & \\
\hline & After Spin-off & 0.029 & & 0.007 & & 0.007 & & 0.001 & & 0.026 & \\
\hline \multirow{2}{*}{$\begin{array}{l}\text { BJB } \\
\text { Syariah }\end{array}$} & Before Spin-off & 0.121 & $*$ & 0.494 & $*$ & 0.377 & $*$ & 0.440 & $*$ & 0.805 & $*$ \\
\hline & After Spin-off & 0.001 & & 0.213 & $*$ & 0.119 & $*$ & 0.029 & & 0.375 & $*$ \\
\hline \multirow{2}{*}{$\begin{array}{l}\text { Bukopin } \\
\text { Syariah }\end{array}$} & Before Spin-off & 0.121 & $*$ & 0.494 & $*$ & 0.377 & $*$ & 0.440 & $*$ & 0.001 & \\
\hline & After Spin-off & 0.001 & & 0.213 & $*$ & 0.119 & $*$ & 0.029 & & 0.375 & $*$ \\
\hline
\end{tabular}

* = Data in normal distribution

Table 5. Recap of Result of Asymp. Sig. Value (2-tailed) Wilcoxon Test

\begin{tabular}{|c|c|c|c|c|c|c|}
\hline $\begin{array}{l}\text { Bank } \\
\text { Name }\end{array}$ & $\begin{array}{c}\text { Market } \\
\text { Share }\end{array}$ & ROA Ratio & NPM Ratio & $\begin{array}{c}\text { Total Asset } \\
\text { Turnover } \\
\text { Ratio }\end{array}$ & CIR & \\
\hline \multirow{2}{*}{$\begin{array}{l}\text { BRI } \\
\text { Syariah }\end{array}$} & 0.000 & * $\quad 0.408$ & 0.056 & 0.044 & 0.011 & $*$ \\
\hline & Positive & & & Negative & Positive & \\
\hline
\end{tabular}


Journal of Innovation in Business and Economics Vol. 01 No. 02 December 2017

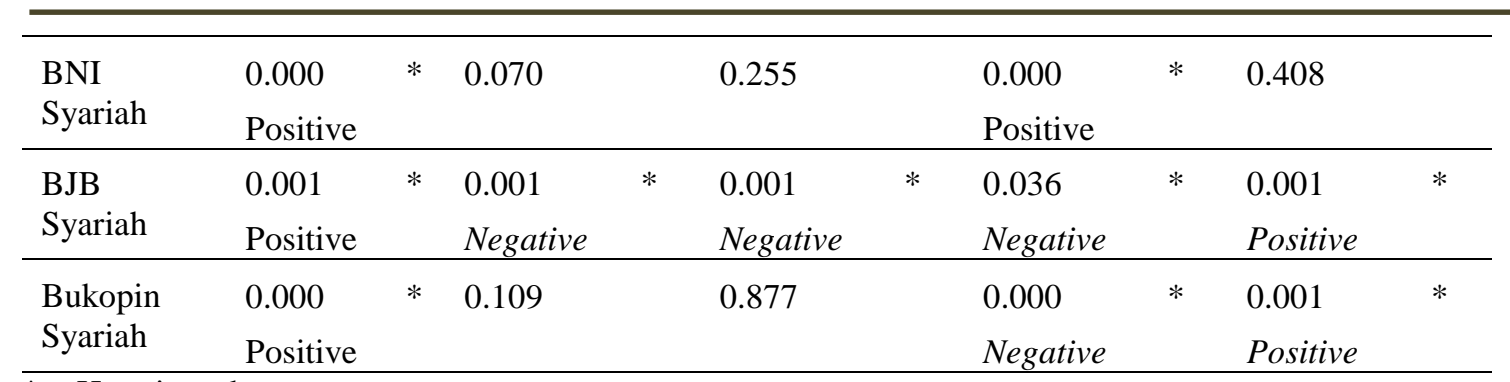

* $=$ Ho rejected

The result of hypothesis test on the ratios of ROA and NPM gives the same results, i.e. first decision rejects Ho, that is at BJB Syariah with the result of mean negative rank (marked with italic letters). This means that the ratios of ROA and NPM of BJB Syariah after spin-off are lower or drop significantly compared to the period before spin-off. This result of test of the ratios of ROA and NPM on BJB Syariah contradicts to the initial hypothesis which expected the ratios of ROA and NPM would increase after the spin-off. Meanwhile, for other three BUSs, namely BRI Syariah, BNI Syariah, and Bank Syariah Bukopin, the decision of hypothesis test is that the Ho is not rejected. This means that there is no significant difference in the ratios of ROA and NPM between the period before and after the spin-off. In 3 BUSs that have the ratios of ROA and NPM that are not significantly different between the periods before and after the spinoff, this occurs because the increase in profit is still at the same level as the increase in assets, both in the period of before and after the spin-off. Meanwhile at BJB Sharia, the ratios of ROA and NPM dropped in the period of after the spin-off, because of lower profit level deriving from high operating cost and fund cost.

The result of hypothesis test on the Total Asset Turnover ratio for 4 Sharia banks produces the decision of rejecting Ho. This means that there is significant difference in the Total Asset Turnover ratio between the period before the spin-off and the period of after the spin-off. But if viewed individually, there is only 1 Sharia bank which Total Assets Turn Over ratio increased after spin-off with the result of mean positive rank. In contrast, 3 other Sharia banks see their ratio drop in the period of after spin-off with the result of mean negative rank (marked with italic letter).

The Sharia bank that sees an increase in the Total Asset Turnover ratio after spin-off is BNI Syariah, unlike BRI Syariah, BJB Syariah and Bank Syariah Bukopin which experienced a decline in the profitability ratio after spin-off. Such drop in the Ratio of Total Assets Turnover in the period after spinoff is because of lower Operating Income compared to increase in Total assets. In other words, even though both rates increase, the growth rate of operating income is still left behind the growth rate of Total Assets. The main income of bank business is from channeling of funds (credit/financing), hence increase in total assets should ideally be contributed by increase in credit/financing. Meanwhile for BUS as a result of spinoff that is experiencing an increase in capital, it cannot automatically and directly be channeled to financing. If this is the case, such distribution of capital will be placed in the form of other productive assets, which rate of "return" is not as high as the return generated from channeling of credit/financing. This causes the growth of operating income lower than the growth of assets itself. This is reflected from data on comparison between total financing channeled against the total assets of the 4 BUSs as a result of spin off. For BRI Syariah, the ratio of financing to the total assets dropped to $81 \%$ compared to the period before the spin-off which was $96 \%$.

BNI Syariah also experienced the same thing that is a drop to $70 \%$ from initially $73 \%$. The Ratio in Bank Syariah Bukopin also dropped to $73 \%$ from initially $77 \%$. Only BJB Syariah experienced an increase in the ratio of financing to total assets, i.e. $74 \%$ from initially $69 \%$ in the period of before spin-off. The banking condition in general for the same period as used in this research, namely 5 years before and after spin-off, based on the data of profitability represented by the ROA ratio, shows that the ROA ratio of conventional banks is not different when compared between the period of before and after the spin-off. In the period of 5 years before the spin-off, the average ROA ratio was $2.8 \%$ and the period after spin off the average ratio ROA remained $2.8 \%$. The same case happened in the sharia banking industry in general which average ROA ratio slightly decreased in the period of 5 years before and after spin-off, namely from $1.6 \%$ to $1.4 \%$.

Compared with the banking condition which was in general relatively stable in the same period 
above, it can be concluded that spin-off cannot yet increase the profitability of BUS in the initial years. The causative factors are among others, addition of BUS capital cannot be directly channeled to financing and high increase of operating cost related to labor and other operating costs. Viewed from the aspect of risk, the condition of BUS asset quality is certainly very influential in terms of the ability to generate profit. Bad asset quality will affect the ability of BUS in generating income, high cost of funds, and high reserve cost for loss that must be formed.

Table 6 indicates that the NPF ratio of BRI Syariah is quite high, in which in year 2014 the ratio was already above $4 \%$ and continued to rise in 2015 . The same is the case for BJB Syariah, which NPF ratio increased significantly in year 2012 to be over $4 \%$, then dropped to below $2 \%$, but again worsened to over 5\% in year 2014 and continued to rise in year 2015. Meanwhile at Bank SyariaBukopin, significant decline of NPF ratio began to occur in year 2012 up to 2015, but in year 2015 managed to lower the NPF ratio down below $3 \%$. The only BUS as a result of spin off that successfully maintains its NPF ratio at a relatively moderate level is BNI Syariah.

The CIR ratio test on the 4 Sharia banks in table 6 gives various results. Result of test on BNI Syariah records no difference between the period of before and after the spin-off. Whereas for BRI Syariah, BJB Syariah and Bank Syariah Bukopin, there is evidence of difference in CIR ratio between the period of before and after the spin-off. The ideal condition expected in the CIR ratio is that this ratio declines after the sharia bank carries out a spin-off, which means that the sharia bank operations more efficiently. However, in table 6, we see that BRI Syariah, BJB Syariah and Bank Syariah Bukopin have positive rank in the CIR ratio in the period of after spin-off. Decreasing operational efficiency after the spin-off process in BRI Syariah, BJB Syaria and Bank Syariah Bukopin, is caused by significant increase in the operating costs which exceeds the capacity of BUS in generating net income. Increased operating cost in these 3 BUSs is caused by increase in the account of administration and general cost, labor cost and other costs.

As for the condition of banking in general for the same period that is used in this research, namely 5 years before and after spin-off, the data on bank operational efficiency represented in the BOPO ratio, indicates that conventional banks' operational efficiency is improving. In the period of 5 years before the spin-off, the average BOPO ratio of conventional banks is $85.2 \%$, whereas the period of 5 years after the spin-off, the average ratio of BOPO dropped to $76.5 \%$. Unlike the general condition in conventional banks, what happens in the sharia banking is contrary namely worsening level of operational efficiency. In the period of 5 years of research before the spin-off, the average BOPO ratio of sharia banking was $78.8 \%$, whereas in the period of 5 years after the spinoff, the average BOPO ratio rose to $85.1 \%$. Decreased efficiency in the sharia banking in the research period of 5 years after the spin-off, is likely caused by the condition in year 2014 and year 2015. Indonesia's sluggish economic growth has significant impact on the national banking, especially on sharia banking. In large "size" conventional banks, compared to the 2013 BOPO ratio which is $74.1 \%$, the ratio increased in 2014 and 2015 respectively $76.1 \%$ and $81.5 \%$. Meanwhile for sharia banks with the market share of below 5\% of national banks, from the 2013 BOPO ratio which was $48.6 \%$, it increased in years 2014 and 2015 by respectively $96.9 \%$ and $97.0 \%$. This is due to the condition of decreased income, high fund cost, and increased reserve cost for asset loss that must set up due to worsening quality of BUS assets.

Table 6. NPF Ratio of BUS as a result of spin off years 2010-2015

\begin{tabular}{lllllll}
\hline & 2010 & 2011 & 2012 & 2013 & 2014 & 2015 \\
\hline BRI Syariah & $3.19 \%$ & $2.77 \%$ & $3.00 \%$ & $3.00 \%$ & $4.06 \%$ & $+4.86 \%$ \\
\hline BNI Syariah & $3.59 \%$ & $3.62 \%$ & $2.02 \%$ & $1.86 \%$ & $1.86 \%$ & $2.53 \%$ \\
\hline BJB Syaria & $1.80 \%$ & $1.36 \%$ & $4.48 \%$ & $1.86 \%$ & $5.91 \%$ & $6.93 \%$ \\
\hline Bank SyariaBukopin & $3.80 \%$ & $1.74 \%$ & $4.57 \%$ & $4.27 \%$ & $4.07 \%$ & $2.99 \%$ \\
\hline
\end{tabular}

Source: Publicised BUS report of BRI Syariah, BNIS Syariah, BJB Syaria, Bank Syariah Bukopin years 2010-2015 


\section{Conclusions, suggestions and limitations}

The process of UUS spin-off to be an independent BUS has successfully increased the market share of BUS in the national banking industry. Data from the 4 samples of BUS which are the result of UUS spin-off indicates that the total assets of each BUS during the period of 5 years after the spin-off, experienced a significant increase. This means that the strategy of UUS spin-off that have been applied has conformed to the theory and the purpose of spin-off, specifically to increase the market share in the national banking industry. This increase in total assets is driven by one important factor for the growth of bank namely increased assets from the result of merger of BUK conversion with UUS that is spun-off (BRI Syariah and Bank Syariah Bukopin), as well as injection of initial capital injection for new BUSs (BNI Syariah and BJB Syariah).

Unlike the result as indicated by the market share ratio above, in which BUSes experienced an increase in their market share, research on the profitability ratio before and after spin-off shows different result. With respect to the profitability ratios of ROA and NPM, the result of research was obtained after the period of 5 years after spin-off, under which the capacity of most BUSs to generate profit on assets was not proven to have significant difference. One of the 4 research samples instead shows result contrary to the expectation of spin-off. This sample is BJB Syariah, which Ratios of ROA and NPM dropped significantly in the period of 5 years after the spin-off. The cause of drop in the BJB Syariah's Ratios of ROA and NPM is its BUS profit increase level that cannot match or is lower than the increase rate of Total Assets. This lower profit level is caused by high operating cost and high fund cost, as well as CKPN cost caused by high NPF ratio because of worsening asset quality.

Another profitability ratio that was examined is the Ratio of Total Assets Turnover, which result of research shows that the spin-off successfully increase the BUS's capability in generating income against the average total assets in only 1 research sample, namely BNI Syariah. Whereas, for the other 3 research samples, this is not proven. The result of research instead suggests that the profitability of the 3 BUSs, namely BRI Syariah, BJB Syariah, and Bank Syariah Bukopin, dropped significantly 5 years after the spinoff. The cause of decline of the Ratio of Total Assets Turnover is lower increase level of Operating Income compared to the increase in Total assets, because increased BUS capital cannot automatically be directly channelled to financing. If this is the case, the distribution of the capital will be placed in the form of other productive assets, which "return" level is not as high as the return deriving from channelling of credit/financing. Meanwhile, BNI Syariah successfully increases its ratio of Total Assets Turnover because the bank can control its operating costs, fund costs, and maintain the quality of assets at a relativelymoderate level.

In terms of efficiency, it is proven that only 1 BUS namely BNI Syariah that does not show difference in the capability to improve operational efficiency 5 years after the spin-off. However, the majority of research results on 3 other BUSs, shows the result in contrary to the expectation of spin-off implementation. BRI Syariah, BJB Syariah and Bank Syariah Bukopin experienced a drop in their CIR ratio within the period of 5 years after the spin-off. Based on existing data, the cause of this deterioration is a significant increase in operating costs that goes beyond 3 BUS's ability to generate net income. The increase in BUS's operating expenses is due to an increase in general and administrative expense accounts, labour costs and other costs. In addition, the deterioration in asset quality that occurs in these three BUSs affects the CIR ratio in terms of its capacity to generate net income.

\section{References}

Al-Saad, M., \&Abdallah, S. (2015). Managing the Spin-Off Process A Case Study from the United Arab Emirates. The Journal of Applied Management and Entrepreneurship Vol. 20 No. 2.

BI. (2009). PBI No. 11/ 15 /PBI/2009 tentangPerubahanKegiatan Usaha Bank KonvensionalMenjadi Bank Syariah. Bank Indonesia.

BI. (2013). PBI No. 15/14/PBI/2013 tentangPerubahanatas PBI No.11/10/PBI/2009 tentang Unit Usaha Syariah. Bank Indonesia.

Chris Veld, \&Merkoulova, Y. V. (2004). Do Spin-offs Really Create Value? The European Case. Journal of Banking and Finance 28 (2004) , 1111-1135.

Farris, P. W., Bendle, N. T., Pfeifer, P. E., \&Reibstein, D. J. (2010). Marketing Metrics: The Definitive Guide to Measuring Marketing Performance. Upper Saddle River, New Jersey: Pearson Education. 
Gaughan, P. A. (2011). Mergers, Acquisitions, and Corporate Restructurings. John Wiley \& Sons, Inc. Gibson, C. H. (2012). Financial Reporting and Analysis. Cengage Learning.

http://www.bi.go.id/id/perbankan/syariah/Contents/Default.aspx. (2014, 12 14). Retrieved from http://www.bi.go.id/: http://www.bi.go.id/id/perbankan/syariah/Contents/Default.aspx

Jumingan. (2011). AnalisaLaporanKeuangan. BumiAksara.

Khan, A. Q., \& Mehta, D. R. (1996). Voluntary Divestatures and The Choice Between Sell-Offs and SpinOffs. The Financial Review Vol. 31 No. 4, 885-912.

Money Week - Cost/Income Ratio. (2013, May 28). Retrieved from Money Week: (http://moneyweek.com/glossary/cost-income-ratio/)

Muharomah, I. A. (2013). PerbandinganKinerjaKeuangan Bank Syariah SebelumdanSesudahPemisahan / Spin-off (StudiKasus pada BNI Syariah dan BRI Syariah).

Nakanishi, Cooper, L. G., \& Masao, a. (2010). Market-Share Analysis - Evaluating Competitive Marketing Effectiveness. Kluwer Academic Publisher.

Nasuha, A. (2012). Dampal Kebijakan Spin-off TerhadapKinerja Bank Syariah. Al-Iqtishad Vol. IV No. 2 Juli 2012.

OJK. (2015). StatistikPerbankan Syariah. Jakarta: OtoritasJasaKeuangan.

OJK. (2015). SuratEdaran OJK No. 18/SEOJK.03/2015 TentangTransparansidanPublikasiLaporan Bank Umum Syariah dan Unit Usaha Syariah. OtoritasJasaKeuangan.

Ross, S. A., Westerfield, R., \& Jaffe, J. F. (2010). Corporate Finance. Mc Graw Hill.

Santoso, S. (2014). StatistikNonParametrikEdisiRevisi .Elex Media Komputindo.

Simbolon, C. T. (2013). AnalisisPerbandinganKinerjaKeuangan Perusahaan SebelumdanSesudahDivestasi

UU No. 21 tahun 2008 tentangPerbankan Syariah. (2008). 